DOI https://doi.org/10.32837/app.v0i66.707

УДК 32:316.647.5

\author{
А. В. Іванова \\ orcid.org/0000-0001-5630-3623 \\ кандидат політичних наук, \\ стариий викладач кафедри політичних теорій \\ Національного університету «Одеська юридична академія»
}

\title{
ПОЛІТИКО-ПРАВОВИЙ СТАН ЗАХІДНОЇ МОДЕЛІ ПОЛІТИЧНОЇ ТОЛЕРАНТНОСТІ В УМОВАХ КРИЗИ
}

Постановка проблеми. В сучасних умовах усе більшого поширення отримують цінності західної цивілізації, що створює нову політичну, правову, культурну та соціальну реальність, де процеси лібералізації та демократизації стають мегатрендом і пріоритетним шляхом розвитку для більшості держав. Трансформаційні зміни торкнулися не тільки державно-політичних інститутів, а й усіх сфер суспільного життя.

Зразком толерантності нині прийнято вважати країни Європейського Союзу та США. I це не безпідставно, оскільки держави мають великий досвід правотворчої та правозастосовної діяльності у сфері захисту прав і свобод людини. Однак ліберально-демократична система цих країн зазнає викликів сучасності, коли політичні рішення і всередині суспільства, і на міжнародній арені нерідко провокують негативні реакції у вигляді бунтів, масових демонстрацій, що супроводжуються погромами, активізацією діяльності антисистемних формувань тощо. Це формує умови розвитку кризових явищ в особливості цінностей та інститутів демократії, що випливає $з$ дезінтеграційної політики.

Встановлення демократичних цінностей, провідне місце серед яких займає й політична толерантність, є досить тривалим і багаторівневим процесом. Саме західні держави є центрами поширення демократичних свобод, які стали характерною платформою глобалізації. Своєрідною опозицією глобальної культури стає традиціоналізм, який різними методами намагається сповільнити та протистояти процесу демократизації шляхом встановлення меж і захисту традиційних основ з метою збереження власної ідентичності. Криза відносин традиційної та західної культурної спільноти й політизація цих відмінностей стали фактором протистояння та дезінтеграційних процесів всередині західних суспільств, що спричинило деструктивні тенденції у розвитку демократичних цінностей.

Найактуальнішою проблемою демократичних країн стає міграційна криза, міграційна політика та пов' язані з нею суспільні реакції: антитолерантні відносини до мігрантів, політична криза, активізація радикальних рухів, терористичні хвилі. Таким чином в умовах розвинутої моделі демократії розповсюджується феномен політичної нетерпимості, який насамперед витікає із публічної політики та формує проекцію соціально-політичних відносин. Саме тому актуалізується проблема дослідження тенденцій розвитку західної моделі інституту толерантності та ії політичних форм у особливості в умовах кризи.

Метою дослідження $є$ аналіз характеристик ефективності та особливостей функціонування моделі політичної толерантності західних держав, визначення інституціональних практик розвитку цього інтеграційного формату співіснування, виявлення кризових явищ і тенденцій впливу на формування антитолерантних явищ у західному суспільстві та всередині політичних еліт.

Аналіз основних досліджень і публікацій. Тема дослідження демократичних інститутів та цінностей є досить розкритою в роботах як вітчизняних, так і зарубіжних дослідників. Однак тема специфіки та моделей політичної толерантності отримала не достатню визначеність змісту та висвітлення лише окремих аспектів ії функціонування такими вченими як Л. Баєва, C. Хенкін, I. Кудряшова, О. Шерман, В. Шалін та іншими. Тому проблема потребує розширення та подальших досліджень.

Інститут толерантності, формування толерантного, етичного суспільства розглядається як практична модель вирішення проблеми розколу суспільства і глобалізаційної близькості 
проблем всіх учасників міжнародних відносин. Отже, визначена проблема має своє вираження і в суспільно-політичних реаліях західного суспільства, а саме в антиноміях, зближенні-закритості, асиміляції-ідентичності. Дезінтеграційні тенденції, які торкнулися і зразкової демократичної системи, виражаються у формах екстремізму, радикалізму, поширенні терористичних організацій. Тероризм стає одним із найвпливовіших чинників кризи толерантних цінностей європейців.

Розділення європейського суспільства на міграційні та антиміграційні рухи провокує політичне розділення і країн, і соціальних страт. В умовах кардинальних настроїв суспільства політичні еліти та політичні лідери теж займають протилежні позиції - на підтримку мігрантів або за закриття кордонів. Звісно, хвиля біженців торкнулася і політичної, і економічної, культурної сфери цього питання. Антиміграційні настрої мали місце і раніше, однак, якщо підставою попереднього стану відносин було негативне ставлення до трудової міграції, то нині це завдає масштабного удару по економіці європейських держав.

Основний закон, який регулює толерантні відносини у європейських державах, представлений у Декларації принципів терпимості від 16 листопада 1995 року. Європейська правозахисна система здійснює діяльність в рамках органу Ради Європи. Європейський суд з прав людини (далі - ЄСПЛ) виконує глобальну правозахисну функцію і представляє один із найавторитетніших органів захисту прав та свобод людини у Європі. ЄСПЛ є незалежним міжнародним органом, встановленим згідно з Свропейською конвенцією про права людини. Конвенція є угодою, за якою держави-учасниці Ради Європи - організації, діяльність яких присвячено захисту принципів демократії, верховенства права і поваги до прав людини, - повинні забезпечувати певні загальновизнані права людини (Бисага, Палінчак, Бєлов, Данканич, 2003).

У підпункті 5.11 Довідника з європейського законодавства про недискримінацію вказується на особливий статус права на політичну думку та поширеність позитивних рішень ЄСПЛ щодо захисту прав на вираження політичних переконань. Також можна згадати висновки ЄСПЛ щодо рішення у справі «Варганян проти Вірменії», незважаючи на те, що суд не задовольнив позов за недостатніми доказами щодо жорстокого затримання у зв'язку з певними політичними поглядами, однак роз'яснив: «Вільні вибори та свобода вираження думок, у тому числі свобода політичних дебатів, складають основу будь-якої демократичної системи».

Було вказано і на особливу обмеженість можливостей держави встановлювати які-небудь заборони на вираження політичної думки (Handbook on European non-discrimination law, 2018, р. 222). В якості прикладу позитивного рішення наведено прецедент 2012 року «Ридферн проти Сполученого Королівства», у якому йдеться про звільнення з роботи водія, який перевозив громадян азіатської зовнішності. На думку заявника, причиною було те, що він $є$ учасником крайньої правої расистської політичної партії. ЄСПЛ знайшов порушення статті 11 Конвенції про захист прав людини і основоположних свобод і зробив висновки, що стаття 11 може застосовуватися не тільки до організацій і громадян, які $з$ точки зору сприйняття є позитивними, а тих, чиї погляди «зневажають, шокують і хвилюють» (Handbook on European non-discrimination law, 2018).

Політична толерантність згідно з європейською правозахисною практикою розповсюджується на різного роду погляди, навіть які не є позитивними чи загальноприйнятними, однак у цьому правовому просторі виникає нова проблема меж толерантності. Саме питання, де саме ці погляди отримають форму небезпечних і стають втіленням зла, наприклад терористичні, екстремістські, потребують обмеження принципу політичної толерантності. У цьому аспекті виникає підгрунтя, на основі якого в сучасному європейському суспільстві розгортається конфлікт традиціоналізму та ліберально-демократичних цінностей. Необмежена свобода слова в особливостях публічних виступів неодноразово спричиняла певний спалах між ісламським світом і представниками європейської спільноти.

У США подібним до органу ЄСПЛ у Свропі для захисту прав і свобод людини виступає Верховний Суд США, який так само має повноваження тлумачення норм конституції в кожному індивідуальному випадку. Існує досвід посилання Європейського суду з прав людини на практику Верховного Суду США. В американській правовій системі приділено досить значну увагу захисту прав і свобод. Основним правовим документом, який регулює права та 
свободи людини, є Конституція США. Одним із основних документів про свободи людини став Білль про права, який складається із 10 прийнятих поправок, внесених до Конституції США, який став фундаментом розвитку законодавства у сфері захисту права людини, в тому числі політичного.

В основному міжнародному правовому документі - Конвенції про захист прав людини і основоположних свобод від 4 листопада 1950 року окреслено право на свободу різних поглядів в рамках визначених демократичних меж, у тому числі політичних. Не менш цінний політико-правовий документ, що регулює права і свободи людини, який застосовується в європейській практиці регулювання політичної толерантності, - Міжнародний пакт про громадянські і політичні права, прийнятий 16 грудня 1966 року Генеральною Асамблеєю ООН, який, у тому числі, ратифікований США.

У статті 2 вказано про право на політичну свободу вибору у вигляді зобов'язання країн-учасників цього пакту «поважати і забезпечувати усім особам права, хто перебуває у межах iї території та під іiі юрисдикцією, визнані у цьому Пакті, без будь-якої різниці щодо раси, кольору шкіри, статі, мови, релігії, політичних чи інших переконань, національного чи соціального походження, майнового стану, народження чи іншої обставини» (Міжнародний пакт про громадянські і політичні права, 1966, ст. 2). Важливу правову цінність для творення засад толерантності має Загальна декларація прав людини від 10 грудня 1948 року, в якій у статтях 18 і 19 визначено право на свободу думки, свободу переконань: «Кожна людина має право на свободу переконань і на вільне вираження їх» (Загальна декларація прав людини, 1948, ст. 19).

Рівність права жінок на політичне вираження зазначено в документі Конвенції ООН про ліквідацію усіх форм дискримінації щодо жінок від 3 вересня 1981 року. Це важливий документ правового регулювання захисту жінок в США і Європі. На рівні визначення інших свобод саме політична сфера зазначається на першому місці.

Дискримінацією у статті 1 визначається «будь-яке розрізнення, виняток або обмеження за ознакою статі, спрямовані на ослаблення чи зведення нанівець визнання, користування або здійснення жінками незалежно від їхнього сімейного стану на основі рівноправності чоловіків і жінок, прав людини та основних свобод у політичній, економічній, соціальній, культурній, громадській або будь-якій іншій галузі» (Конвенція Організації Об'єднаних Націй про ліквідацію усіх форм дискримінації щодо жінок, 1981, ст. 1). Конкретне розроблення програми дій і розвитку засад толерантності, в тому числі політичної, врегульовано міжнародним документом, а саме прийнятою на Всесвітній конференції з прав людини від 25 червня 1993 року Віденською декларацією та Програмою дій. Важливо зауважити, що в цьому документі роз'яснено комплексний підхід необхідних засад і дій держав у напрямі встановлення прав і свобод людини.

Важливий і такий міжнародно-правовий акт як Хартія основних прав Свропейського Союзу від 7 грудня 2000 року, у якому систематизовано основні права та свободи. Окремі сторони регулювання, які застосовуються у європейському правовому просторі, в межах політичних відносин, політичних прав і свобод, політичної терпимості має своє відображення в Декларації про права осіб, які належать до національних або етнічних, релігійних і мовних меншин від 18 грудня 1992 року, Резолюції 36/55 Генеральної Асамблеї ООН «Декларація про ліквідацію усіх форм нетерпимості та дискримінації на основі релігії чи переконань» від 25 листопада 1981 року, Міжнародній конвенції про ліквідацію всіх форм расової дискримінації від 4 січня 1969 року, Міжнародному пакті про економічні, соціальні і культурні права від 16 грудня 1966 року, Рамковій конвенції про захист національних меншин від 1 лютого 1995 року та інших правових документах.

Варто зазначити, що в основних документах європейських правових практик здебільшого не використовується поняття «політичної терпимості», а застосовується лише в окремих аспектах, наприклад терпимість до вираження політичних поглядів і подібні формулювання. Це становить проблему недостатньої конкретизації толерантних відносин у сфері політичних взаємодій. Незважаючи на широкий спектр правових документів, практичне зобов' язання держав-учасників до впровадження законодавства та законодавчих норм, передбачення реальних покарань у цій сфері, діє лише у вигляді деяких рекомендацій. 
Проект Європейської рамкової конвенції з розвитку толерантності та боротьби з нетерпимістю від 10 листопада 2008 року так і не був прийнятий. Його можна вважати спробою створення окремого національного закону у сфері толерантності. Це могло запровадити практику, яку перейняли б інші країни не тільки в межах Європейського Союзу. Окрім практичного значення, теоретичну цінність вказаного проекту складає визначення предметної сторони феномену толерантності та глибока інтерпретація дій і діяльності, які можна вважати нетерпимістю. Вона засновані на різних критеріях, серед яких «політично або ідеологічно мотивована, а також мотивована расовими відмінностями діяльність або дії, які здійснюються окремими особами, групами або державами проти осіб, груп або спільнот», як зазначається у статті 3 цього проекту. У статті 1 визначається толерантність як «не тільки моральна відповідальність, а як політична і законна необхідність» (Проект Європейської рамкової конвенції 3 розвитку толерантності та боротьби з нетерпимістю, 2008, ст. 3).

Під час аналізу цього проекту було виявлено відсутність спрямованості на попередження політичної нетерпимості та норм, спрямованих на забезпечення толерантних відносин у контексті політичних поглядів, а лише окремі визначення загальних аспектів попередження антидискримінаційних засад політичних суджень. У правовому сенсі інтерес викликає те, що вперше у подібному документі було акцентовано увагу на зобов' язанні, було прийнято конкретне законодавство з визначенням норми толерантності та передбаченого покарання за порушення. Однак введення покарань за нетерпимість у різного роду виявах, починаючи від підбурення, образ, погроз, публічних висловлювань та інших виявів нетерпимості, відсутнє у кримінальному законодавстві держав-учасників.

На існуючу проблему в європейському соціумі вказав президент Європейської ради з толерантності та взаємоповаги на засіданні круглого столу Європейської ради з толерантності та взаємоповаги в Монако 6 березня 2018 року. На його думку, саме утворення «нового мультикультурного мислення» європейського суспільства та нового законодавства складає основне спрямування розвитку засад толерантності. Він акцентує увагу на принципі «безпечної та надійної толерантності», необхідність якої полягає у попередженні формування глобальних форм нетерпимості: «Ставлячи поза законом не тільки теракти, а й словесні наміри».

У промові було зазначено, що загальний пасивний підхід до бачення толерантності передбачає «виключно попередження явних порушень прав людини при їх виникненні». Однак існує потреба регулювання толерантності не тільки на стадії ліквідації наслідків, а й у ії стабільному стані. Маються на увазі ефективні розробки попередження, а не ті, які мають рекомендаційний характер. «Попередження означає спрямування уваги на ті області, де загроза радикалізації особливо велика». (Речь президента ЕСТП Вячеслава Моше Кантора на заседании круглого стола Европейского совета по толерантности и примирению, 2018). Запропонований погляд особливо важливий і для українських реалій в аспекті проблем радикальних течій.

Країни Європейського Союзу прийнято вважати центром реалізації толерантних засад, демократичних прав і свобод. Однак у світлі сучасних геополітичних змін країни перебувають у стані захисної реакції як відповідної реакції на події. Стан страху за свою ідентичність все більше поширюється в європейській свідомості. У згаданій промові президент Свропейської ради з толерантності та взаємоповаги вказав на основні чинники, які зробили європейську ідентичність вразливою, а нормативну форму толерантності - застарілою: економічна рецесія 2008 року; поліцентричність світу; еміграція; зміна соціальної структури суспільства; втрата «лібералізму, технократичної еліти та політичного центру», розуміння причин і наслідків криз; «необмежена толерантність і політкоректність»; неактуальне мислення; відсутність законодавчих ініціатив. Новий формат мислення та законодавчих новацій повинні стати, на його думку, фундаментом ефективного впровадження толерантності у європейський простір і подолання існуючих негативних тенденцій (Речь президента ЕСТП Вячеслава Моше Кантора на заседании круглого стола Европейского совета по толерантности и примирению, 2018).

Питання інтеграційної політики держав в аспекті міграційної нетерпимості нині стають на рівень загальної міжнародної проблеми. Незважаючи на міжнародну позицію до міграційної проблеми, США - одна із держав, яка відкрито презентує власні інтереси вище міжнародних. Як повідомляє газета The Guardian, Америка вийшла з глобального договору ООН щодо мі- 
грації, підкресливши, «що участь у цьому процесі суперечить американському суверенітету та імміграційній політиці США» (The Guardian, 2017). Отже, спостерігається не тільки криза міграції, а й політична криза міжнародних відносин, міжнародних угод і стандартів. Ці заяви відбуваються на фоні мексиканської міграційної кризи.

Однією з визначених проблем інтолерантності до мігрантів є політика, яка пропагує нетерпимість у своїй публічній риториці. Науковець О. Шерман розглядає проблему вияву нетерпимості, породжену негативними стереотипами до мігрантів, в контексті яких утворюється модель «свої-чужі». Сприйняття мігрантів як небезпечних суб'єктів грунтується на ідеологічній та ціннісно-культурній відособленості. Особливими передумовами формування такої дистанції є певна інтолерантна риторика політичних лідерів, антиміграційні ініціативи радикальних партій та організацій, пропаганда нетерпимості в медіапросторі (Шерман, 2009, с. 69). Таким чином, ксенофобія та нетерпимість загалом застосовуються як засіб пропаганди.

Питання міграції в риториці політичної нетерпимості стає особливо актуальним для всіх країн у глобалізаційну епоху, що не обійшло і США. Так, після виборів президента у 2017 році були організовані акції на підтримку мігрантів у відповідь на підписання Д. Трампом імміграційної директиви в січні 2017 року про заборону в'їзду на 90 днів громадянам мусульманських країн (Іран, Сомалі, Судан, Смен, Сирія та Лівія). Акції протесту відбулися у 65 містах Америки. Не залишилися без відповідної реакції і захисники антиімміграційних настоїв. Так, були організовані мітинги на підтримку передвиборчих гасел Д. Трампа про депортацію мільйона мігрантів, які активно транслювалися новообраним президентом США, до них приєдналися і праворадикальні організації. Згодом президентська угода була скасована федеральним судом.

Ще найбільша проблема назріває в контексті мексиканської міграції. Наріжним каменем кризи в американському суспільстві стала антиміграційна політика Д. Трампа «нульової толерантності» до міграції. Внаслідок цього у затриманих мексиканських біженців, як повідомляє портал новин ВBC news Україна «з 5 травня по 9 червня на кордоні понад 2300 дітей розлучили 3 батьками» (BBC news Україна, 2018). Це також отримало широку реакцію американської спільноти. Інститут Геллапа у 2017 року оприлюднив дані дослідження, в яких було зазначено, що лише 36\% американців підтримують зведення стіни між США та Мексикою (Brenan, 2018). Тому можна зазначити, що нетерпимість виходить із політичної влади, саме ж суспільство сприймає такий поділ прав людей як незаконний і дискримінаційний. Головним суб'єктом нетерпимості виступають саме офіційні представники держави, політики, владні суб'єкти.

Як зазначають дослідники С.М. Хенкін та І.В. Кудряшова, за останні десятиліття в європейських країнах (Германія, Франція, Великобританія) підхід до інтеграції мігрантів кардинально змінився від етнокультурної концепції нації - необхідності кровної спорідненості до критерію народження, проживання та прийняття основних принципів і цінностей держави. Проте змінилася і політика «невтручання» та «багатокультурності» до «керованого мультикультуралізму» щодо таких закритих спільнот, які входили у суспільство, внаслідок відсутності контролю з боку держави, формувалися в настільки закриті та неконтрольовані структури, що призводило до фрагментації та неоднорідності самого соціуму в особливості після хвилі терористичних атак, які вразили європейську спільноту (Хенкин, Кудряшова, 2015).

Серед складників проблем соціального дисбалансу сучасних європейських країн слід визначати не тільки інтолерантність до культурних меншин у вигляді мігрантів, а й переваження культурною меншістю пануючої культури, відмежування від неї, створення закритих спільнот всередині соціуму та розвиток нетерпимості до корінного населення. Ця проблема є одним із важливих чинників розвитку кризи інституту толерантності у Європі та світі. Одним із ії фундаментальних складників $є$ проблема толерантності до інтолерантності. В умовах абсолютизації принципу терпимості до «чужого» існує небезпека придушення основної культури.

Як зазначає вітчизняний дослідник К.М. Вітман, в умовах неконтрольованої толерантності існує небезпека утворення політичних течій, які шукатимуть підтримки в радикальних утвореннях. Дослідник зазначає: «Найбільшим виявом ксенофобії (мігрантофобії), протестом проти толерантності до інтолерантності став подвійний теракт у Норвегії (вибух в Осло та розстріл молоді на острові Утойя) 2011 року, під час якого загинуло 93 особи. Організатор 
теракту А. Брейвік у такий спосіб намагався зупинити наплив мігрантів до Європи. У маніфесті під назвою «Декларація незалежності Європи 2083 року» він звинуватив західноєвропейських політиків у слабкості перед ісламською експансією і пояснив вбивства необхідністю порятунку Свропи від мультикультуралізму (Вітман, 2011, с. 263).

Нещодавно після нового видання «Шарлі Ебдо» карикатури на Пророка Мухаммеда у Франції було скоєно кілька терористичних нападів. Виступаючи з цього приводу, президент Е. Макрон заявив, що ці рисунки є свободою слова і європейське суспільство не буде відмовлятися від цього права. Він зазначив, що іслам переживає кризу. Це викликало протести на ближньому сході, засудження політики необмеженої свободи Макрона. Навіть лідери деяких країн виразили нерозуміння такої позиції.

Так, ми бачимо позицію захисту толерантності. Якщо така карикатура ображає релігійні почуття тисяч мусульман, чи є толерантними до них, до їх релігійних цінностей подібні публічні виступи? Отже, зіткнення західноєвропейської та мусульманської моделі цінностей формує деструктивні наслідки у суспільстві. Публічна політика, яка підтримує нетолерантне ставлення до цінностей релігії, представляє цілу цивілізацію, ще більше дестабілізує відносини західних і східних суспільств. Нині західноєвропейська модель політичної толерантності переживає кризу якраз через проблему необмеженої толерантності та свободи.

У Західній Європі зростає кількість антиміграційних мітингів, радикальних рухів, «розквітають» праві радикальні політичні сили. Як зазначив дослідник, на таку хвилю терактів проти мігрантів були публічні заяви політичних лідерів, які підтримали дії А. Брейвіка. Це свідчить про кризу толерантності насамперед у політичній спільноті. Чий принцип абсолютності толерантності зазнав краху і створив зворотній ефект поширення інтолерантних настроїв серед суспільства? Криза міграційної толерантності вже має значну історію розвитку. Нині ми спостерігаємо за наслідками тривалої відсутності комплексних заходів щодо регулювання цієї проблеми.

Важливим фактором впливу на стан розвитку інституту толерантності стають не тільки політичні погляди, а саме економічні можливості, особливо щодо трудової міграції, рівності прав і можливостей. Соціальний та економічний розрив можливостей основного населення та міграційних спільнот поглиблює проблему нетерпимості з обох сторін.

На думку дослідниці Л.В. Баєвої, «конфліктогенність, породжена нерівномірністю розвитку країн, продовжує посилюватися й отримувати новий імпульс, оскільки в період панування «світових стандартів» відмінності надто різко вирізняються і дратують жителів бідних країн. Хвиля етнічних терактів, які періодично спалахують у європейських країнах, гсвідчить про те, що проблеми третього світу не вирішилися відкриттям кордонів. Ці проблеми змінили місце вияву, тепер вони - невід'ємна частина історії новітнього часу усіх континентів» (Баева, 2009, с. 72)

Висновки. Узагальнюючи тему, можна зазначити, що сучасна дійсність характеризується досить проблематичним впровадженням інституту політичної толерантності і в розвинених, і в нових демократіях, що відображає проблему недостатньої розробленості практичних механізмів утвердження цього політичного інституту. 3 огляду на аналіз наведених практик можна вказати на досить розвинену законодавчу базу, судову систему та розвинену структуру державних, неурядових, громадських організацій у сфері розвитку інституту толерантності та попередження виявів нетерпимості в США та країнах Європейського Союзу.

На прикладі міграційної кризи толерантності визначені проблемні аспекти, які насамперед репрезентуються у сфері офіційної політики держав. Тому подолання існуючих проблем встановлення інституту політичної толерантності потребує не тільки організаційно-регулятивних засад, а й особливостей державно-політичних механізмів балансування та реагування на зміни внутрішньодержавної і міжнародної сфери політики.

\section{Лiтература}

Баева Л.В. (2009). Толерантность: идея, образы, персоналии : монография. Астрахань : Издательский дом «Астраханский университет», 217.

Бисага Ю.М., Палінчак М.М., Бєлов Д.М., Данканич М.М. (2003). Міжнародні засоби захисту прав та свобод людини і громадянина. Ужгород, 57.

Вітман К.М. Криза толерантності. Наукові праці НУ «ОЮА». <http:/ /www.naukovipraci.nuoua.od.ua/ arhiv/tom10/26.pdf> (2020, жовтень, 15). 
Загальна декларація прав людини (1948). Офіиійний сайт Верховної Ради України <zakon.rada.gov.ua/ laws/show/995_015> (2020, жовтень, 15).

Конвенція Організації Об'єднаних Націй про ліквідацію усіх форм дискримінації щодо жінок (1981). Офіиійний сайт Верховної Ради України <zakon.rada.gov.ua/laws/show/995_207> (2020, жовтень, 15).

Міграційна криза в США (2018). ВВС пешьs Україна. <https:/ /www.bbc.com/ukrainian/features-44572475> (2020, жовтень, 15).

Міжнародний пакт про громадянські і політичні права (1966). Офіційний сайт Верховної Ради України. <http://zakon.rada.gov.ua/laws/show/995_043> (2020, жовтень, 15)

Проект Європейської рамкової конвенції з розвитку толерантності та боротьби з нетерпимістю (2008) World holocaust forum foundation www.worldholocaustforum.org/media/dte/framework.pdf (2020, жовтень, 15).

Речь президента ЕСТП Вячеслава Моше Кантора на заседании круглого стола Европейского совета по толерантности и примирению (2018) <http:/ / moshekantor.com/> (2020, october, 15).

Хенкин С.М., Кудряшова И.В (2015). Интеграция мусульман в Европе: политический аспект. Политические исследования, 2, с. 137-155.

Шерман О.М. (2009) Чужі проти своїх: реальний і міфологічний виміри негативного стереотипу мігрантів. Науковии вісник Ужгородського університету, 12, с. 68-73.

Brenan M. (2018) Record-High 75\% of Americans Say Immigration Is Good Thing. Gallup. $<$ https://www.gallup.com/corporate/212336/what-we-do.aspx> (2020, october, 15).

Handbook on European non-discrimination law (2018). Luxembourg: Publications Office of the European Union. <https://www.echr.coe.int/Documents/Handbook_non_discri_law_ENG.pdf> (2020, october, 15).

\section{References}

Baeva L.V. (2009). Tolerantnost: ideya, obrazy, personalii [Tolerance: idea, images, personalities] : monografiya. Astrahan : Izdatelskij dom "Astrahanskij universitet", 217 [in Russian].

Brenan M. (2018). Record-High 75\% of Americans Say Immigration Is Good (Thing. Gallup) Retrieved from: https://www.gallup.com/corporate/212336/what-we-do.aspx [in English].

Bysaga Yu.M., Palinchak M.M., Byelov D.M., Dankanych M.M. (2003). Mizhnarodni zasoby zaxystu prav ta svobod lyudyny i gromadyanyna [International means of protection of human and civil rights and freedoms]. Uzhgorod, 57 [in Ukrainian].

Handbook on European non-discrimination law (2018). (Publications Office of the European Union). Retrieved from: https://www.echr.coe.int/Documents/Handbook_non_discri_law_ENG.pdf [in English].

Henkin S.M., Kudryashova I.V (2015). Integraciya musulman v Evrope: politicheskij aspekt [Integration of Muslims in Europe: political aspect]. Politicheskie issledovaniya, 2, 137-155 [in Russian].

Konvenciya Organizaciyi Obyednanyx Nacij pro likvidaciyu vsix form dyskryminaciyi shhodo zhinok (1981). [United Nations Convention on the Elimination of All Forms of Discrimination against Women] (Oficijnyj sajt Verxovnoyi Rady Ukrayiny). Retrieved from: zakon.rada.gov.ua/laws/show/995_207 [in Ukrainian].

Migracijna kryza v SShA (2018). [The migration crisis in the United States] (BBC news Ukrayina). Retrieved from: https://www.bbc.com/ukrainian/features-44572475 [in Ukrainian].

Mizhnarodnyj pakt pro gromadyanski i politychni prava (1966). [International Covenant on Civil and Political Rights] (Oficijnyj sajt Verxovnoyi Rady Ukrayiny) Retrieved from: http:/ / zakon.rada.gov.ua/laws/ show/995_043 [in Ukrainian].

Proekt Yevropejskoyi ramkovoyi konvenciyi z rozvytku tolerantnosti ta borotby z neterpymistyu (2008). [Draft European Framework Convention for the Development of Tolerance and Combating Intolerance] (World holocaust forum foundation). Retrieved from: www.worldholocaustforum.org/media/dte/framework.pdf [in Ukrainian].

Rech prezidenta ESTP Vyacheslava Moshe Kantora na zasedanii kruglogo stola Evropejskogo soveta po tolerantnosti i primireniyu (2018). [Speech by ECT President Vyacheslav Moshe Kantor at the round table of the European Council on Tolerance and Reconciliation]. Retrieved from: http://moshekantor.com/ [in Russian].

Sherman O.M. (2009). Chuzhi proty svoyix: realnyj i mifologichnyj vymir negatyvnogo stereotypu migrantiv [Strangers against their own: the real and mythological dimension of the negative stereotype of migrants]. Naukovyj visnyk Uzhgorodskogo universytetu, 12, 68-73 [in Ukrainian].

Vitman K.M. (2011). Kryza tolerantnosti [Crisis of tolerance] (Naukovi praci NU "OYuA"). Retrieved from: http:/ / www.naukovipraci.nuoua.od.ua/arhiv/tom10/26.pdf [in Ukrainian].

Zagalna deklaraciya prav lyudyny (1948). [Universal Declaration of Human Rights] (Oficijnyj sajt Verxovnoyi rady Ukrayiny). Retrieved from: zakon.rada.gov.ua/laws/show/995_015 [in Ukrainian]. 


\section{Анотація}

Іванова А. В. Політико-правовий стан західної моделі політичної толерантності в умовах кризи. - Стаття.

Інститут толерантності отримав широкий розвиток у західній моделі демократії. Саме західні країни представляють зразковий формат реалізації принципів та інструментів ефективного впровадження толерантних засад. Розвиненіша законодавча база та правозахисна практика є основами для розбудови інституцій толерантності в західних суспільствах. У цій статті розглянуто та проаналізовано основні компоненти західної моделі політичної толерантності, проведено аналіз політико-правових механізмів регулювання інституту, розкрито сучасні кризові тенденції політичної толерантності та чинники впливу на їх формування.

Проведено теоретичний аналіз політико-правових документів, проектів і концепцій розвитку інституту політичної толерантності в західній правовій системі, компонентів ефективності та проблем реалізації принципів толерантності саме в політичній сфері як на міжсоціальному рівні, так і на рівні внутрішньополітичних відносин суб'єктів.

Особливу увагу у статті приділено проблемам публічної риторики, проекції політичної нетерпимості серед представників політичної влади, політичних лідерів як чинникам формування кризи толерантності в західних суспільствах. У статті розглянуто чинники конфлікту традиціоналізму та ліберально-демократичних цінностей як умови розвитку дезінтеграційних процесів у європейському суспільстві, формування стану закритості, міграційної нетерпимості, крайніх форм інтолерантності, радикалізму, екстремізму та тероризму, які стали новітніми умовами існування європейської спільноти.

Визначним напрямом дослідження є аналіз засад, механізмів, принципів і методів розбудови інституту толерантності, особливостей регулювання, виявлення проблемних тенденцій і перспектив розвитку толерантності в реаліях західної моделі демократії. Досить важливим напрямом $є$ виявлення чинників впливу на формат мислення, ціннісні аспекти європейського суспільства в умовах кризи. Акцентується увага не тільки на дослідженні розвитку демократичних інститутів у західних державах, а й на аналізі досвіду кризових станів, особливостей функціонування демократичних інституцій в умовах нестабільності.

Ключові слова: демократизація, лібералізація, політична толерантність, права і свободи, західна демократія.

\section{Summary}

Ivanova A. V. Political and legal state of the Western model of political tolerance in a crisis. - Article.

The institution of tolerance has been widely developed in the Western model of democracy. It is Western countries that represent an exemplary format for implementing the principles and tools for the effective implementation of tolerant principles. A more developed legal framework and human rights practice is the basis for building institutions of tolerance in Western societies. This article considers and analyzes the main components of the Western model of political tolerance, analyzes the political and legal mechanisms of regulation of the institution, reveals the current crisis trends of political tolerance and the factors influencing their formation.

The author conducted a theoretical analysis a theoretical analysis of political and legal documents, projects and concepts of development of the institution of political tolerance in the Western legal system, components of efficiency and problems of implementation of tolerance principles in the political sphere both at the social level and at the level of domestic relations. The article pays special attention to the problems of public rhetoric and the projection of political intolerance among representatives of political power, political leaders as a factor in the formation of the crisis of tolerance in Western societies.

The article considers the factors of the conflict of traditionalism and liberal-democratic values as conditions for the development of disintegration processes in European society and the formation of a state of closedness, migration intolerance, extreme forms of intolerance, radicalism, extremism and terrorism. An outstanding area of research is the analysis of the principles, mechanisms, principles and methods of building the institution of tolerance, the peculiarities of regulation, identifying problematic trends and prospects for the development of tolerance in the realities of the Western model of democracy.

An outstanding area of research is to identify factors influencing the format of thinking, the value aspects of European society in a crisis. This is important not only in the context of studying the development of democratic institutions in Western countries, but also in terms of analyzing the experience of crises, the peculiarities of the functioning of democratic institutions in conditions of instability.

Key words: democratization, liberalization, political tolerance, rights and freedoms, Western democracy. 